\title{
DAMPAK SERTIFIKASI GURU TERHADAP PENINGKATAN KUALITAS PENDIDIKAN DI MADRASAH DI KOTA PALU
}

\section{THE IMPACT OF TEACHER CERTIFICATION ON THE IMPROVEMENT OF EDUCATION QUALITY IN MADRASAH}

\author{
Badruzzaman \\ Balai Penelitian dan Pengembangan Agama Makassar \\ Jl. A.P. Pettarani No. 72 Makassar 90222 \\ Email: bz69elzam@gmail.com
}

Naskah diterima tanggal 14 April 2016. Naskah direvisi tanggal 29 April 2016. Naskah diterima tanggal 3 Juni 2016

\begin{abstract}
Abstrak
Penyelenggaraan sertifikasi guru yang dilakukan sejak tahun 2007 tersebut membutuhkan evaluasi untuk mengetahui tingkat ketercapaian program, khususnya dampaknya terhadap peningkatan kualitas pendidikan di madrasah. Oleh karena itu, penelitian bertujuan untuk mengetahui keterlibatan guru sertifikasi terhadap peningkatan kualitas pendidikan di madrasah, sebagai dampak penyelenggaraan sertifikasi guru. Penelitian evaluatif menggunakan bersaran sampel berdasarkan Formula Nomogram Herry King pada signifikansi 5\%. Hasil penelitian menunjukkan bahwa tingkat dampak sertifikasi guru terhadap peningkatan kualitas pendidikan di MA di Sulawesi Tengah terkategori "tinggi". Meskipun demikian tingkat keterlibatan i responden terhadap peningkatan yang dimaksud masih variatif yaitu "sangat rendah" sampai "sangat tinggi". Hal ini dapat dicermati pada aspek dan indikator dampak, yaitu dampaknya terhadap peningkatan kualitas perencanaan terkategori "sangat tinggi", kualitas pelaksanaan program "tinggi", kualitas proses pembelajaran "sangat tinggi", dan kompetensi sesama guru "sangat tinggi". Guru sertifikasi masih dominan memanfaatkan tunjangan sertifikasinya pada pemenuhan kebutuhan dasarnya (kepentingan pribadi dan keluarga) dibanding pada peningkatan kualitas profesi, sehingga terkategori "sangat rendah". Penelitian juga menemukan keragaman tingkat dampak sertifikasi guru pada peningkatan kualitas pendidikan madrasah berdasarkan perbedaan usia saat disertifikasi, lama mengajar, jalur sertifikasi, penyelenggara sertifikasi, status madrasah, dan status keguruan dan kepangkatan.
\end{abstract}

Kata Kunci: Sertifikasi guru, kualitas madrasah, dampak sertifikasi

\begin{abstract}
The implementation of teacher certification since 2007 require an evaluation to determine the level of achievement of the program, particularly its impact on improving the quality of education in madrasas. Therefore, the study aims to determine the involvement of teacher certification to improve the quality of education at the school, as the impact of the implementation of teacher certification. Evaluative research using a sample based Formula nomogram Harry King recomendation at the 5\% significance. The results showed that the level of teacher certification impact on improving the quality of education in MA in Central Sulawesi categorized "high". Despite this level of involvement or sumbangsi respondents to the increase in question is varied from "very low" to "very high". It can be observed on the aspects and impact indicators, namely the impact on improving the quality of planning categorized "very high", the quality of the implementation of the program "high", the quality of the learning process "very high", and fellow teacher competence "very high". Teacher certification is still dominant utilize the benefits of certification to the fulfilment of their basic needs (personal interests and family) than on improving the quality of the profession, it is categorized "very low". The study also found the different level of teacher certification impact on improving the quality of madrasah education by the age difference when they were certified, the duration of the teaching, the path to certification, the certification, the status of madrassas and teacher status and rank.
\end{abstract}

Keywords : teacher, certification, quality of madrasah, Palu 


\section{PENDAHULUAN}

$\mathrm{U}$ ndang-Undang Nomor 14 Tahun 2005 tentang Guru dan Dosen menegaskan bahwa guru adalah pendidik professional dengan diberikan tugas utama mendidik, mengajar, mambimbing, mengarahkan, melatih, menilai, dan mengevaluasi peserta didik pada pendidikan usia dini jalur pendidikan formal, pendidikan dasar, dan pendidikan menengah (Undang-Undang Republik Indeonesia Nomor 14 Tahun 2005 Tentang Guru dan Dosen, Pasal 1 Ayat 1). Pengakuan kedudukan guru sebagai tenaga profesional dibuktikan dengan sertifikat pendidik (Undang-Undang Republik Indeonesia Nomor 14 Tahun 2005 Tentang Guru dan Dosen, Pasal 2).

Berbagai upaya telah dilakukan oleh pemerintah untuk menunaikan amanah regulasi peningkatan kualitas dan kesejahteraan guru melalui sertifikasi, termasuk di madrasah. Salah satunya adalah Peraturan Menteri Keuangan Republik Indonesia Nomor 71/PMK.07/2011 Tentang Pedoman Umum dan Alokasi Tunjangan Profesi Guru Pegawai Negeri Sipil Daerah Kepada Daerah Provinsi, Kabupaten, dan Kota Tahun Anggaran 2011 Pasal 2 (1) sejumlah Rp. 18.537.689.880.200,00. Selanjutnya pada tahun 2012 sebesar 30.559.800.000.000,00, dan 2013 sebanyak Rp43.057.800.000.000,00.

Dana tersebut digunakan untuk penghitungan portofolio dan PLPG. Pada tahun 2011 Direktorat Madrasah Kementerian Agama RI telah menyertifikasi sejumlah 38.000 pengawas dan guru madrasah melalui Pemberian Sertifikasi Pendidik secara Langsung (PSPL) sementara sertifikasi guru dalam jabatan melalui jalur pendidikan sejumlah 2.400 orang. Dan pada tahun 2012 Direktorat Madrasah telah menyertifikasi sejumlah 2.400 orang guru agama melalui jaur pendidikan (http://pendis.kemenag.go.id). Selain itu, dalam rangka peningkatan mutu dan kompetensi guru madrasah, Kementerian Agama RI melanjutkan kegiatan sertifikasi bagi guru serta mempercepat dan mengefektifkan penyelenggaraan kegiatan yang dimaksud dengan mengeluarkan daftar urut prioritas (long list) calon peserta sertifikasi bagi guru RA/Madrasah dalam jabatan untuk mata pelajaran keagamaan (Quran Hadits, Akidah Akhlak, Fiqh, SKI), Bahasa Arab, guru kelas RA, guru kelas MI dan guru mata pelajaran umum tahun 2013 (http:// madrasah.kemenag.go.id)
Sertifikasi guru madrasah sebagai upaya peningkatan mutu guru diharapkan dapat meningkatkan mutu pembelajaran dan mutu pendidikan agama di Indonesia secara berkelanjutan. Dengan adanya sertifikasi pemerintah berharap kinerja guru akan meningkat sehingga proses pendidikan dan prestasi siswa meningkat.

Sejumlah program sertifikasi, membutuhkan evaluasi untuk mengetahui tingkat ketercapaian program. Sungguh banyak perhatian, dana, tenaga dan waktu yang dialokasikan kepada kegiatan sertifikasi guru mulai dari persiapan sertifikasi, pelaksanaan sertifikasi, sampai kepada pemberian tunjangan sertifikasi. Namun informasi tentang dampak penyelenggaraan serifikasi guru terhadap peningkatan kualitas pendidikan, khsususnya di madrasah, sampai saat ini belum diperoleh data yang akurat. Oleh karena itu, evaluasi tentang keterlibatan guru sertifikasi terhadap peningkatan kualitas pendidikan di madrasah, sebagai dampak penyelenggaraan sertifikasi guru madrasah urgen dilakukan. Hasil penelitian diharapkan memberikan input akurat kepada pemerintah tentang keberhasilan sertifikasi guru di madrasah Informasi akurat ini, nantinya dapat dijadikan bahan pertimbangan teknis dalam melanjutkan kegiatan sertifikasi guru.

Berdasarkan latar belakang penelitian, maka yang menjadi fokus permasalahan dalam penelitian ini adalah bagaimana dampak sertifikasi guru terhadap peningkatan kualitas pendidikan di madrasah? Lebih khusus masalah penelitian adalah bagaimana tingkat keterlibatan guru sertifikasi terhadap peningkatan kualitas pendidikan di madrasah sebagai dampak penyelengaraan sertifikasi guru?

Penelitian ini bertujuan untuk mengetahui tingkat ketelibatan guru sertifikasi terhadap peningkatan kualitas pendidikan di madrasah, meliputi peningkatan kualitas perncanaan program madrasah, pelaksanaan program, proses pembelajaran, peningkatan kompetensi sesama guru, dan pemanfaatan tunjangan sertifikasi pada pengingkatan profesi. Penelitian diharapkan dapat bermanfaat teoritis terhadap peningkatan fenomena ilmu pendidikan, khususnya terhadap pengelolaan pendidikan keagamaan; dan diharapkan dapat bermanfaat praktis terhadap kebijakan Kementerian Agama RI dalam meningkatakan kualitas guru madrasah. 


\section{Tinjauan Pustaka}

Banyak usaha yang telah dilakukan oleh pemerintah untuk meningkatkan kualitas pendidikan, salah satu diantaranya adalah dengan meningkatkan kualitas guru. Hal ini dapat dipahami karena kualitas sistem pendidikan secara keseluruhan berkaitan erat dengan kualitas guru. Guru memiliki peran yang strategis dalam bidang pendidikan, bahkan sumber pendidikan lain yang memadai seringkali kurang berarti apabila tidak didukung oleh keberadaan guru yang berkualitas. Dengan kata lain, guru merupakan ujung tombak dalam upaya peningkatan kualitas layanan dan hasil pendidikan. Singkatnya, guru merupakan kunci utama dalam upaya peningkatan kualitas pendidikan.

Pengakuan kedudukan guru sebagai tenaga profesional dibuktikan dengan cara melakukan sertifikasi bagi guru dalam jabatan. Selanjutnya, bagi guru yang telah memiliki sertifikat pendidik berhak memperoleh penghasilan di atas kebutuhan hidup minimum dan jaminan kesejahteraan sosial. Penghasilan di atas kebutuhan hidup minimum meliputi gaji pokok, tunjangan yang melekat gaji, serta penghasilan lain berupa tunjangan profesi, tunjangan fungsional, tunjangan khusus, dan maslahat tambahan yang terkait dengan tugasnya sebagai guru yang ditetapkan dengan prinsip penghargaan atas dasar prestasi. Hal ini sesuai dengan tujuan diadakannya sertifikasi guru, yaitu: (1) menentukan kelayakan seseorang dalam melaksanakan tugas sebagai agen pembelajaran; (2) peningkatan mutu proses dan hasil pendidikan; dan (3) peningkatan profesionalisme guru (Dikti, 2006).

Menurut Undang-undang Nomor 14 Tahun 2005, tentang Guru dan Dosen, sertifikat pendidik diberikan kepada guru/dosen yang telah memenuhi persyaratan kualifikasi akademik dan kompetensi sebagai agen pembelajaran. Sertifikat pendidik diberikan kepada seseorang yang telah menyelesaikan program pendidikan profesi pendidik dan lulus ujian sertifikasi guru. Dalam hal ini, uji sertifikasi guru dimaksudkan sebagai pengendalian mutu hasil pendidikan, sehingga seseorang yang dinyatakan lulus dalam uji sertifikasi guru diyakini akan mampu melaksanakan tugas mendidik, mengajar, melatih, membimbing, dan menilai hasil belajar peserta didik.

Dalam Permendiknas Nomor 18 Tahun 2007, tentang Sertifikasi Guru Dalam Jabatan, tersirat bahwa empat kompetensi guru profesional ini dapat diukur melalui 10 komponen, yaitu: (1) kualifikasi akademik, (2) pendidikan dan pelatihan, (3) pengalaman mengajar, (4) perencanaan dan pelaksanaan pembelajaran, (5) penilaian dari atasan dan pengawas, (6) prestasi akademik, (7) karya pengembangan profesi, (8) keikutsertaan dalam forum-forum ilmiah, (9) pengalaman organisasi di bidang kependidikan dan sosial, dan (10) penghargaan yang relevan dengan bidang pendidikan (Permendiknas No.18 2007, tentang Sertifikasi Guru Dalam Jabatan, pasal 2 ayat 3).

Sertifikasi guru dilakukan dengan tiga pola, yaitu a. penerbitan sertifikat pendidik secara langsung (PSPL), b. portofolio (PF), dan c. pendidikan dan pelatihan profesi guru (PLPG). atau (d) Pendidikan Profesi Guru (PPG). Pola Penerbitan Sertifikasi Pendidik secara Langsung diperuntukan bagi guru yang memenuhi persyaratan memiliki kualifikasi akademik S-2/S-3 dan sekurangkurangnya golongan IV/b (Kementerian Pendidikan Dan Kebudayaan, Buku 1, 2012: 13) Pola penilaian portofolio diperuntukkan bagi guru yang berprestasi dan memiliki kesiapan diri. Guru berprestasi adalah guru yang sekurang-kurangnya memiliki satu prestasi dalam bidang akademik atau karya pengembanga profesi yang mendapat pengakuan dari lembaga yang kredibel, minimal tingkat kabupaten/kota.Guru memiliki kesiapan diri adalah guru yang memiliki dokumentasi atau bukti fisik atas pencapaian prestasi/karya yang diperkirakan memenuhi kriteria kelulusan. (Kementerian Pendidikan Dan Kebudayaan, Buku 3, 2012: 3) Peserta sertifikasi pola PLPG adalah guru yang bertugas sebagai guru kelas, guru mata pelajaran, guru bimbingan dan konseling atau konselor, serta guru yang diangkat dalam jabatan pengawas satuan pendidikan yang memilih: (1) sertifikasi pola PLPG, (2) pola PF yang berstatus tidak mencapai passing grade penilaian portofolio atau tidak lulus verifikasi portofolio (TLVPF), dan (3) PSPL tetapi berstatus tidak memenuhi persyaratan (TMP) yang lulus UKA. (Kementerian Pendidikan Dan Kebudayaan, Buku 2, 2012: 7)

Jalur penilaian fortofolio dan jalur pendidikan dan latihan dinilai belum mampu meningkatkan kompetensi dan menimbulkan kecurangan. Oleh sebab itu, khususnya sertifikasi guru di luar jabatan, sebaiknya pemberian sertifikat guru hanya diberikan kepada calon guru yang telah menempuh 
pendidikan profesi yang diselenggarakan oleh LPTK.

Dampak, menurut Soemarwoto, adalah suatu perubahan yang terjadi sebagai akibat suatu aktifitas. Selanjutnya Soemarwoto menjelaskan : "aktifitas tersebut bisa bersifat alamiah, berupa kimia, fisik maupun biologi, dapat pula dilakukan oleh manusia berupa analisis dampak lingkungan, pembangunan dan perencanaan. Adapun dampak tersebut dapat bersifat biofisik, sosial, ekonomi dan budaya."(Soemarwoto, 2004: 23). Dampak kebijakan adalah keseluruhan efek yang ditimbulkan oleh suatu kebijakan dalam kondisi kehidupan nyata (Dye, 1981: 367). Sertifikasi guru merupakan salah satu kebijakan pemerintah dalam rangka meningkatkan kualitas pendidikan. Bagaimanapun sebuah kebijakan, menimbulkan dampak, baik itu dampak positif maupun negatif. Dampak positif dimaksudkan sebagai dampak yang memang diharapkan akan terjadi akibat sebuah kebijakan dan memberikan manfaat yang berguna bagi lingkungan kebijakan. Sedangkan dampak negatif dimaksukan sebagai dampak yang tidak memberikan manfaat bagi lingkungan kebijakan dan tidak diharapkan terjadi.

Beberapa penelitian tentang sertifikasi guru, dominan mengamati dampak atau pergaruh penyelenggaraan sertifikasi guru terhadap peningkatan kualitas guru. Hasil penelitian yang dilakukan oleh Suwardi, menyimpulkan bahwa setifikasi bendampak positif terhadap perbaikan kualitas guru, perlindungan terhadap profesi guru, perbaikan kesejahteraan guru, peningkatan minat masyarakat menjadi guru, meningkatkan administrasi pendidikan, dan meningkatkan motivasi guru dalam melaksanakan kerja ilmiah. Sementara dampak negatif yang telah diidentifikasi antara lain adanya kecurangan yang dilakukan oleh guru dalam menyusun portofolio, kadangkala sertifikasi guru dapat mengganggu proses pembelajaran, menimbulkan kesenjangan dan kecemburuan bagi guru lain (eprints. stainsalatiga.ac.id). Penelitian yang dilakukan oleh Dadang Sunendar, Yoyoh Jubaedah, Tri Indri Hardin menemukan, bahwa pada umumnya guru yang telah mengikuti sertifikasi mengalami peningkatan kompetensi dan memberikan dampak positif terhadap sikap profesionalisme guru. Kondisi ini mengimplikasikan bahwa, sertifikasi guru melalui penilaian fortofolio memberikan dampak terhadap peningkatan profesionalisme guru, walalupun guru-guru SMA Negeri di Jawa
Barat masih mengharapkan peningkatan dan pengembangan melalui pelatihan-pelatihan yang berkaitan dengan profesionalisme guru (lppm.upi. edu). Fatchurrohman melakukan penelitian tentang pengaruh sertifikasi guru bagi peningkatan kinerja guru si SMP Negeri 1 Salahtiga menemukan bahwa sertifikasi guru berdampak terhadap peningkatan kedisiplinankerja dan kedisiplinan administratif akademik (eprints.stainsalatiga. ac.id). Penelitian yang dilakukan oleh Prof. Dr. Djemari Mardapi dkk. mencoba melihat dampak sertifikasi guru terhadap peningkatan presitasi sekolah, menyimpulkan bahwa ada perbedaan dampak kompetensi guru yang telah disertifikasi dengan guru yang belum disertifikasi terhadap prestasi akademik dan non akademik siswa.

Penelitian terakhir mengamati dampak sertifikasi dengan menjadikan output penyelenggaraan sertifikasi sebagai sasaran penelitian, yaitu guru yang telah disertifikasi. Penelitian kuantitatif ini tidak lagi mengamati proses penyelenggaraan penelitian dan dampaknya, namun lebih memfokuskan pengamatan pada kompetensi guru yang telah disertifikasi dan pengaruhnya terhadap peningkatan prestasi peserta didik.

Kualitas pendidikan menurut Ace Suryadi dan H.A.R Tilaar merupakan kemampuan lembaga pendidikan dalam mendayagunakan sumbersumber pendidikan untuk meningkatkan kemampuan belajar seoptimal mungkin.(Suryadi, 1993: 159 ) Jadi dalam hal ini kualitas pendidikan diukur pada tingkat kemampuan suatu lembaga pendidikan mencapai keberhasilan.

Kualitas pendidikan mengacu pada proses pendidikan dan hasil pendidikan. Dari konteks "proses" pendidikan yang berkualitas terlibat berbagai input (seperti bahan ajar: kognitif, afektif dan, psikomotorik), metodologi (yang bervariasi sesuai dengan kemampuan guru), sarana sekolah, dukungan administrasi dan sarana prasarana dan sumber daya lainnya serta penciptaan suasana yang kondusif. Dengan adanya manajemen sekolah, dukungan kelas berfungsi mensingkronkan berbagai input tersebut atau mensinergikan semua komponen dalam interaksi (proses) belajar mengajar, baik antara guru, siswa dan sarana pendukung di kelas atau di luar kelas, baik dalam konteks kurikuler maupun ekstra-kurikuler, baik dalam lingkungan substansi yang akademis maupun yang non akademis dalam suasana yang mendukung proses belajar pembelajaran. 
Kualitas dalam konteks "hasil" pendidikan mengacu pada hasil atau prestasi yang dicapai oleh sekolah pada setiap kurun waktu tertentu (apakah tiap akhir cawu, akhir tahun, 2 tahun atau 5 tahun, bahkan 10 tahun). Prestasi yang dicapai atau hasil pendidikan (student achievement) dapat berupa hasil test kemampuan akademis, misalnya ulangan umum, EBTA atau UN. Dapat pula prestasi dibidang lain seperti di suatu cabang olah raga, seni atau keterampilan tambahan tertentu. Bahkan prestasi sekolah dapat berupa kondisi yang tidak dapat dipegang (intangible) seperti suasana disiplin, keakraban, saling menghormati, kebersihan dan sebagainya. Selain itu kualitas pendidikan merupakan kemampuan sistem pendidikan dasar, baik dari segi pengelolaan maupun dari segi proses pendidikan, yang diarahkan secara efektif untuk meningkatkan nilai tambah dan faktor-faktor input agar menghasilkan output yang setinggitingginya.

Jadi pendidikan yang berkualitas adalah pendidikanyang dapat menghasilkan lulusan yang memiliki kemampuan dasar untuk belajar, sehingga dapat mengikuti bahkan menjadi pelopor dalam pembaharuan dan perubahan dengan cara memberdayakan sumber-sumber pendidikan secara optimal melalui pembelajaran yang baik dan kondusif. Pendidikan atau sekolah yang berkualitas disebut juga sekolah yang berprestasi, sekolah yang baik atau sekolah yang sukses, sekolah yang efektif dan sekolah yang unggul. Sekolah yang unggul dan bermutu itu adalah sekolah yang mampu bersaing dengan siswa di luar sekolah. Juga memiliki akar budaya serta nilai-nilai etika moral (akhlak) yang baik dan kuat.

Mengukur tingkat kualitas pendidikan hendaknya mengacu pada Peraturan Pemerintah Republik Indonesia Nomor 13 Tahun 2015 tentang Perubahan Kedua Atas Peraturan Pemerintah Nomor 19 Tahun 2005 Tentang Standar Nasional Pendidikan tentang Standar Nasional Pendidikan. Pada Standar Nasional Pendidikandi atas, ada delapan hal yang harus diperhatikan untuk mewujudkan pendidikan yang berkualitas, yaitu: Standar Kompetensi Lulusan, Standar Isi/ Kurikulum, Standar Proses pendidikan, Standar Pendidik dan Tenaga Kependidikan, Standar Sarana dan Prasarana, Standar Pengelolaan, Standar Pembiayaan, dan Standar Penilaian Pendidikan

\section{METODE PENELITIAN}

Penelitian bertujuan mengevaluasi kebijakan Kementerian Agama berkaitan dengan program sertifikasi guru (penelitian evaluatif) dalam rangka memberikan informasi akurat sebagai dasar kebijakan selanjutnya untuk meningkatkan kualitas pendidikan di madrasah (penelitian kebijakan). Penelitian dilakukan di Kota Palu Sulawesi Tengah mengumpulkan data dengan menggunakan kuasioner dan menaganalisisnya dengan statistika deskriptif (penelitian kuantitatif). Besaran Sampel ditarik dengan cara random sampling menggunakan perhitungan Formula Nomogram Herry King pada signifikansi 5\% (Sugiyono, 2010:73). Analisis deskriptif kuantitatif dilakukan untuk menetapkan tingkat dampak sertifikasi diukur berdasarkan kuantifikasi kategori opsi setiap item pertanyaan quesioner, yaitu: sangat tinggi (3,01-4.00), tinggi (2,01-3.00), rendah (1,01-2.00), dan rendah $(0,01-$ $1.00)$.

\section{PEMBAHASAN \\ Deskrispsi Variabel dan Indikator Penelitian}

Penelitian dampak sertifikasi guru terhadap peningkatan kualitas madrasah menfokuskan amatan pada keluaran penyelenggaraan sertifikasi guru madrsah yang selama ini ditangani oleh Kementrian Diknas dan Kementerian Agama. Penelitian ini tidak lagi memfokuskan pada penyelenggaraan sertifikasi guru yang dilaksanakan beberapa perguruan tinggi negeri dan perguruan tinggi agama negeri di beberapa provinsi. Namun penelitian ini mengamati tingkat aktivitas dan peran guru yang telah disertifikasi oleh lembagalembaga penyelenggara itu terhadap peningkatan kualitas madrasah tempat guru tersebut bertugas. Karenanya variabel dan indikator penelitian disusun berdasarkan Standar Pendidikan Nasional untuk mengukur tingkat sumbangsi dan peran guru yang telah disertifikasi terhadap peningkatan kualitas madrasah.

Dari delapan SNP, dipilih beberapa standar yang memiliki keterkaitan langsung, atau dimungkinkan guru dapat berperan, yaitu standar pengelolaan, standar proses pembelajaran, standar pendidik dan tenaga kependidikan, serta sarana prasrana. Secara rinci sub variabel penelitian mencakup: pertama keterlibatan guru sertifikasi pada perencanaan pembelajaran, meliputi: 
penyusunan visi, misi dan tujuan madrasah, serta penyusunan program kerja madrasah.

Kedua keterlibatan guru sertifikasi pada pelaksanaan rancana kerja madasah, bagian ini terdiri atas: Keterlibatan pada penyusunan pedoman madrasah, terdiri atas 10 indikator meliputi: menyusun rencana kerja tahunan madrasah, Kurikulum Tingkat Satuan Pendidikan (KTSP); kalender pendidikan/akademik; struktur organisasi sekolah/madrasah; pembagian tugas di antara guru; pembagian tugas di antara tenaga kependidikan; peraturan akademik; tata tertib sekolah/madrasah; kode etik sekolah/madrasah; biaya operasional sekolah/ madrasah. Keterlibatan pada kegiatan kesiswaan, terdiri atas 8 indikator, meliputi: penerimaan peserta didik; orientasi peserta didik baru yang bersifat akademik dan pengenalan lingkungan tanpa kekerasan; layanan konseling kepada peserta didik; kegiatan ekstra dan kokurikuler untuk para peserta didiik; pembinaan prestasi unggulan; pelacakan terhadap alumni.

Keterlibatan pada peningkatan mutu madrasah, terdiri atas 9 indikator meliputi: peningkatan mutu kegiatan pembelajaran dan program pendidikan tambahan; peningkatan mutu penilaian hasil belajar siswa; pendayaguanaan pendidik dan tenaga kependidikan; pengangkatan tenaga pendidik dan tenaga kependidikan; promosi/ mutasi/ pengembangan pendidik dan tenaga kependidikan; peningkatan pengelolaan sarana dan prasarana madrasah; peningkatan pengelolaan perpustakaan dan laboratorium; dan peningkatan pengelolaan keuangan dan pembiayaan pendidikan. Keterlibatan pada peningkatan mutu pengawasan dan evaluasi madrasah, terdiri atas 5 indikator meliputi: peningkatan mutu kegiatan pembelajaran dan program pendidikan tambahan; peningkatan mutu penilaian hasil belajar siswa; pendayagunaan pendidik dan tenaga kependidikan; pengangkatan tenaga pendidik dan tenaga kependidikan; promosi/ mutasi/ pengembangan pendidik dan tenaga kependidikan; peningkatan pengelolaan sarana dan prasarana madrasah; peningkatan pengelolaan perpustakaan dan laboratorium; peningkatan pengelolaan keuangan dan pembiayaan pendidikan.

Ketiga keterlibatan pada peningkatan kualitas proses pembelajaran, bagian ini terdiri atas: aktivitas guru saat memulai pelajaran, terdiri atas 5 indikator meliputi: memotivasi siswa; mengajak siswa memusatkan perhatian pada materi yang akan diajarkan; mengajak siswa berpartisipasi dalam proses pembelajaran; memperlihatkan atau menujukkan buku-buku yang perlu dipelajari berkaitan dengan materi pelajaran; mengatur tempat duduk siswa.

Aktivitas guru saat melakukan eksplorasi mengajar, terdiri atas 4 indikator, meliputi: menanyai siswa tentang apa saja yang siswa ketahui berkaitan dengan materi yang akan diajarkan; menjelaskan secara detail materi yang diajarkan; mencocokkan pengetahuan yang siswa pahami dengan materi pelajaran yang diajarkan; menjelaskan kembali materi yang diajarkan.

Aktivitas guru saat menyampaikan materi pelajaran, terdiri atas 7 indikator, meliputi: melibatkan siswa dalam proses belajar; menginspirasi siswa ; membuat suasana pembelajaran yang menyenangkan; membuat siswa tertantang untuk mempelajari lebih dalam materi tersebut; membuat siswa termotivasi untuk aktif dalam proses belajar (bertanya, berdiskusi, dan memberikan tanggapan); membuat siswa mandiri; membuat siswa bangga memahami materi pelajaran yang diajarkan.

Sikap guru saat mengajar, terdiri atas 7 indikator meliputi: datang ke kelas sesuai dengan waktunya; memakai pakaian yang sopan, bersih, dan rapi; berbicara dengan tutur kata yanga santun; membuat siswa memahami dengan jelas materi pelajaran; menciptakan ketertiban, kedisiplinan, kenyamanan, keselamatan; menghargai pendapat siswa; menutup pelajaran sesuai dengan waktunya. Aktivitas guru saat menutup pelajaran, terdiri atas 4 indikator, melibat: menyampaikan kesimpulan materi pelajaran; menanyai pemahaman siswa terhadap materi pelajaran; menjelaskan kembali materi pelajaran yang siswa belum pahami; memberikan siswa tugas berkaitan dengan materi pelajaran.

Keterlibatan pada peningkatan kualitas sesama guru, bagian ini terdiri atas: berdiskusi atau memotifasi guru lain dalam menigkatkan kompetensi pedagogik, terdiri atas 10 indikator meliputi: melanjutkan pendidikan ke jenjang strata berikutknya; cara memahami karakteritik siswa; teori belajar dan perinsip-perinsip pembelajaran; pengembangan kurikulum; penyelengaraan kegiatan pengembangan yang bersifat mendidik; pembagian tugas di antara tenaga kependidikan; pemanfaatan TIK; cara memfasilitasi pengembangan potensi siswa; penyelenggaraan penilaian dan evaluasi proses dan hasil belajar. 
Berdiskusi dan memotivasi guru lain dalam meningkatkan kompetensi kepribadian, terdiri atas 5 indikator. meliputi: norma agama, hukum, sosial, dan kebudayaan nasional Indonesia; kepribadian yang jujur, berakhlak mulia, dan teladan; kepribadian yang mantap, stabil, dewasa, arif, dan berwibawa; etos kerja, tanggung jawab yang tinggi, rasa bangga menjadi guru, dan rasa percaya diri; kode etik profesi guru.

Berdiskusi dan memotivasi guru lain dalam meningkatkan kompetensi sosial, terdiri atas 5 indikator meliputi: bersikap inklusif, bertindak objektif, serta tidak diskriminatif; berkomunikasi secara efektif, empatik, dan santun; beradaptasi dengan lingkungan tempat bekerja; berkomunikasi dengan komunitas profesi guru dan profesi lain: berdiskusi dan memotivasi guru lain dalam meningkatkan kompetensi kompetensi professional, terdiri atas 5 indikator meliputi: materi mata pelajaran dan cara menguasainya; standar kompetensi dan kompetensi dasar mata pelajaran dan cara menguasainya; mengembangkan materi pembelajaran; mengembangkan profesionalitas; memanfaatkan teknologi informasi dan komunikasi.

Pemanfaatan tunjangan sertifikasi, terdiri atas pemanfaatan untuk kepentingan pribadi, kepentingan keluarga, kepentingan peningkatan profesi, dan kepentingan sarana/media pembelajaran.

\section{Kondisi Guru di Sulawesi Tengah}

Jumlah guru MA di Sulawesi Tengah pada tahun 2013 sebanyak 4.885 orang. Terdapat sejumlah $58,67 \%$ guru yang berstatus pendidikan sarjana dan $41,33 \%$ guru yang berstatus pendidikan non-sarjana. Dengan demikian hanya sejumlah 2.886 orang guru saja yang berhak untuk mengikuti program sertifikasi guru. Guru MA tampak terkonsetrasi pada empat kabupaten/kota yaitu di Kabupaten Parigi Mountong sebanyak 17\% guru, Banggai 14\% guru, Sigi 14\% guru, dan Donggala $10 \%$ guru (Laporan tahunan Bidang Pendidikan Madrasah Kantor Wilayah Kementerian Agama Sulawesi Tengah).

Sementara jumah guru MA yang telah lulus sertifikasi sejak tahun 2007-2013 sebanyak baru berkisar $11,38 \%$ guru yaitu sejumlah 556 orang guru. Sejumlah tersebut tersebar di 11 kabupaten/ kota. Guru bersertifikasi tersebut terkonsentrasi di empat kabupaten/kota, yaitu Kota Palu (28,8\%),
Donggala (20,5\%), Parigi Mountong (11,9\%) dan Toli-Toli (10,3\%). Demikian halnya dengan keikutsertaan guru pada penyelanggara sertifikasi pun tampak beragam. Dominan guru MA mengikuti program sertifikasi di UNTAD yaitu 56.8\% guru atau sejumlah 316 orang guru dan UIN yaitu $41,7 \%$ atau sejumlah 232 orang guru. Dan hanya sejumlah 8 orang guru MA yang telah mengikuti program sertifikasi guru di UNM (Laporan Tahunan Bidang Pendidikan Madrasah Kantor Wilayah Kementerian Agama Sulawesi Tengah).

\section{Karakteristik Responden}

Berdasar pada teknik sampling digunakan maka jumlah guru MA tersertifikasi yang terjaring adalah sebanyak 110 responden. Berdasarkan kategori usia saat sertifikasi, dominan responden disertifikasi saat berusia 34 tahun - 43 tahun yaitu sejumlah 53.6\% reponden; kemudian menyusul saat responden berusia 54 tahun-60 tahun sebanyak $21.4 \%$ responden. Sementara responden yang lain disertifikasi saat berusia 25 tahun - 33 tahun sebanyak $17.9 \%$ dan 44 tahun-53 tahun sebanyak $7.1 \%$. Pada aspek yang lain, tampak bahwa dominan reseponden telah mengajar selama 5 tahun- 15 tahun yaitu sebanyak separuh dari jumlah responden dan telah mengajar selama 16 tahun-26 tahun yaitu sebanyak $35,7 \%$ responden.

Pada aspek yang lain, yaitu jalur sertifikasi, tampak bahwa keikutsertaan responden pada jalur porptopolio dan PLPG hampir berimbang, yaitu sejumlah 53,6\% responden yang mengikuti jalur portopolio dan $46,4 \%$ responden yang mengikuti jalur PLPG. Namun responden yang mengikuti sertifikasi pada program sertifikasi guru yang diselenggarakan oleh Kemendiknas lebih banyak $(64,3 \%)$ dari pada responden yang mengikuti program sertifikasi yang selenggarakan oleh Kemenag (35,7\%).

Dua aspek terakhir, yaitu status madrasah tempat mengajar dan kepangkatan responden juga tampak bervariasi. Pada aspek pertama, tampak bahwa dominan responden yang mengajar di MAN (71,4\%) dibanding responden yang mengajar di MAS (28.6\%). Aspek terakhir, tampak bahwa dominan responden berpangkat Pembina (Golongan IV/a dan IVb) yaitu sejumlah 39.3\% responden, kemudian menyusul responden yang berstatus honorer (32,1\%), Golongan III/a - III/b $(21,4 \%)$, dan Golongan III/c-III/d (7.1\%). 


\section{Dampak Sertifikasi Guru Terhadap Peningkatan Kualitas Madrasah Deskripsi Analisis Statistika}

Secara umum, tingkat dampak sertifikasi guru terhadap peningkatan kualitas madrasah di Palu terkategori "tinggi". Hal ini dapat dibuktikan dari hasil analisis statistik deskriptif sebagai berikut:

Tabel 1. Hasil Analisis Deskriptif Statistik

\begin{tabular}{cccc}
\hline No & Kategori & Skor & Nilai \\
\hline 1 & Skor Ideal & 568 & $100.00 \%$ \\
2 & Skor Maksimal & 428 & $75.35 \%$ \\
3 & Skor Minimal & 154 & $27.11 \%$ \\
4 & Rata-Rata Skor & 361.82 & $63.70 \%$ \\
5 & Rentang Skor & 274 & $48.24 \%$ \\
\hline 6 & Std Deviasi & \multicolumn{3}{c}{54,82} \\
\hline 7 & Jumlah & \multicolumn{3}{c}{110} \\
\hline 8 & Responden & \multicolumn{3}{c}{$63.70 \%$} \\
\hline
\end{tabular}

Hasil analisis itu menunjukkan bahwa rata-rata skor adalah 361,82, dan bila dibandingkan dengan nilai ideal maka tingkat presentasi pencapaian dampak berada pada 63.70 atau terkategori "tinggi". Namun kategori tinggi pencapaian dampak sertifikasi itu tampaknya belum semaksimal yang diharapkan sebab penyebaran skor-pun tampak tinggi. Hal ini dapat diamati pada rentang skor maksimal: 424 (tingkat pencapaian 75.35) dengan skor minimal 152 (tingkat pencapaian27,11), rentang skor sebesar 247 (48,24), dan standar deviasi 54.82. Karenanya meskipun tingkat dampak sertifikasi guru terhadap peningkatan kualitas madrasah terkategori tinggi, namun tingkat tersebut tampak heterogen, yaitu masih terdapat sejumlah tertentu responden yang memiliki tingkat aktivitas yang terkategori rendah dalam memberikan sumbangsi terhadap peningkatan kualitas madrasah.

Tabel 2. Tingkat Dampak Sertifikasi Guru Terhadap Peningkatan Kualitas Madrasah

\begin{tabular}{|c|c|c|}
\hline No Indikator & Tingk & Dampak \\
\hline 1. Perencanaan & \multicolumn{2}{|r|}{3.14} \\
\hline Pelaksanaan & & \multirow{5}{*}{2.75} \\
\hline a. Penyusunan pedoman madrasah & 2.71 & \\
\hline b. Keterlibatan pada kegiatan kesiswaan & 2.92 & \\
\hline c. Peningkatan mutu madrasah & 2.65 & \\
\hline d. Peningkatan mutu pengawasan dan evaluasi & 2.72 & \\
\hline \multicolumn{3}{|l|}{ 3. Peningkatan Proses Pembelajaran } \\
\hline a. Memulai pelajaran & 3.8 & \multirow{7}{*}{3.72} \\
\hline b. Kegiatan eksplorasi & 3.87 & \\
\hline c. Penyampaian materi pelajaran inti & 3.77 & \\
\hline d. Sikap mengajar & 3.79 & \\
\hline e. Menutup pelajaran & 3.88 & \\
\hline f. Kegiatan pada madrasah induk & 3.09 & \\
\hline g. Disiplin & 3.84 & \\
\hline \multicolumn{3}{|l|}{ 4. Peningkatan Kompetensi Sesama Guru } \\
\hline a. Pedagogik & 3.49 & \multirow{4}{*}{3.68} \\
\hline b. Kompetensi keperibadian & 3.77 & \\
\hline c. Kompetensi sosial & 3.79 & \\
\hline d. Kompetensi profesional & 3.68 & \\
\hline 5. Pemanfaatan Tunjangan Sertifikasi & & 0.33 \\
\hline 6. Jumlah Madrasah Diajar & & 3.82 \\
\hline Total Dampak & & 2.91 \\
\hline
\end{tabular}


Secara detail tingkat dampak sertifikasi guru terhadap peningkatan kualitas madrasah dapat diamati lebih mendalam pada pembahasan berikut:

\section{Tingkat Aktivitas Guru Sertifikasi pada Perencanaan Program Madrasah}

Tingkat ketelibatan guru sertifikasi terhadap perencanaan program madrasah, terkatogori sangat tinggi. Hal ini dapat dibuktikan dari hasil rerata skor dari sejumlah 4 indikator, yaitu 3.14 (sangat tinggi). Tingkat ketelibatan guru terhadap prencanaan madarah itu dapat diamati berdasarkan indikator. Sejumlah $85.7 \%$ guru sertifikasi yang pernah terlibat dalam penyusunan visi dan misi madrasah, $75 \%$ guru sertifikasi pernah terlibat dalam penyusunan tujuan madrasah dan $59.8 \%$ guru yang pernah terlibat dalam penyusunan rencana kerja madrasah.

\section{Tingkat Aktivitas Guru Sertifikasi terhadap Pelaksanaan Rencana Kerja Madrasah}

Ada empat aspek yang diamati dalam hal ketelibatan guru sertifikasi dalam pelakasanaan rencana kerja madrasah, yaitu keterlibatan pada penyusunan pedoman madrasah, kegiatan kesiswaan, peningkatan mutu madrasah, dan peningkatan mutu pengawasan dan evaluasi.

Pertama keterlibatan pada penyusunan pedoman madrasah. Tingkat keterlibatan guru sertifikasi pada penyusunan pedoman madrasah terkategori "tinggi", hal ini dapat dibuktikan pada rerata skor dari 10 indikator, yaitu 2.71. Tingkat ketelibatan guru sertifikasi pada setiap indikator tampak bervariasi. Guru sertifikasi memiliki keterlibatan tinggi pada penyusunan perangkat pembelajaran yaitu penyusunan rencana kerja tahunan, KTSP, kalender akademik, peraturan akademik, pembagian tugas guru, dan stuktur organisasi (tingkat ketelibatan itu mencapai 64.3\% guru sampai $89.3 \%$ guru). Namun keterlibatan guru sertifikasi terhadap penyusunan pedoman pengelolaan madrasah tampak rendah, yaitu antara sejumlah $57.1 \%$ guru sampai $21.4 \%$ guru. Guru sertifikasi kurang terlibat pada penyusunan pedoman pembagian tugas antar tenaga kependidikan, tata tertib madrasah, kode etik madrasah, dan biaya operasional madrasah.

Kedua keterlibatan pada kegiatan kesiswaan madrasah. Tingkat keterlibatan responden pada kegiatan kesiswan terkategori "tinggi" (rerata skor dari delapan indikator adalah 2,65). Keterlibatan guru sertifikasi terhadap setiap indikator tampak bervariasi. Guru sertifikasi tampak terlibat maksimal pada dua indikator yaitu kegiatan penerimaan siswa baru dan kegiatan kokurikuler (di atas $90 \%$ guru yang pernah terlibat). Sejumlah $75 \%-85,1 \%$ responden terlibat pada penyusunan kriteria penerimaan peserta didik, kepanitiaan orientasi siswa baru, pelayanan konseling, dan pembinaan prestasi unggulan siswa. Semetara pada kegiatan pelacakan alumni, jumlah guru sertfikasi yang pernah terlibat hanya $60.7 \%$. Lebih jelasnya dapat dilihat

Ketiga keterlibatan pada peningkatan mutu madrasah. Tingkat ketelibatan guru sertifikasi pada peningkatan mutu madrasah pun tinggi (2.72). meskipun keterlibatan tersebut "tinggi", namun jumlah guru yang terlibat pada setiap indikator tampak bervariasi. Guru sertifikasi tampak banyak terlibat pada peningkatan mutu pembelajaran dan program pendidikan tambahan, peningkatan mutu penilaian hasil belajar, peningkatan pengelolaan perpustakaan dan laboratorium, dan peningkatan program pendidikan tambahan, yaitu antara $71,4 \%$ $94,4 \%$. Sementara pada kegiatan lainnya, tampak tingkat ketelibatn guru sertifikasi terkategiori kurang, khsususnya pada empat indikator (28,6\%-57.1\%).

Keempat peningkatan mutu pengawasan dan evaluasi. Tingkat ketelibatan guru sertifikasi pada peningkatan mutu pengawaasn dan evaluasi terkategori "tinggi" (2,72). Hal ini dapat diamati dengan jelas pada lima indikator untuk mengukur tingkat keterlibatan tersebut. Sejumlah 60,1 \% sampai $75 \%$ responden pernah terlibat dalam upaya peningkatan mutu pengawasan dan evaluasi madrasah. Guru sertifikasi dominan terlibat pada tiga indikator, yaitu: peningkatan mutu pemantauan, supervisi, evaluasi, pelaporan, dan tindak lanjut hasil pengawasan; peningkatan mutu evaluasi diri terhadap kinerja madrasah; dan peningkatan mutu evaluasi pendayagunaan pendidik. Sementara guru sertifikasi sangat tampak kurang terlibat dalam upaya peningkatan mutu evaluasi tenaga kependidikan dan peningkatan status akreditasi madrasah.

\section{Tingkat Ketelibatan Guru Sertifikasi terhadap Peningkatan Proses Pembelajaran}

Terdapat tujuh aspek yang diamati dalam hal mengamati tingkat keterlibatan guru sertifikasi terhadap upaya peningkatan kualitas proses 
pembelajaran. Ketujuh hal itu adalah memulai pelajaran, kegiatan eksplorasi, penyampaian materi pelajaran inti, sikap mengajar, menutup pelajaran, kegiatan pada madrasah induk, dan kedisiplinan.

Pertama peningkatan kualitas pembelajaran saat memulai pelajaran. Tingkat keterlibatan guru sertifikasi terhadap peningkatan kualitas pembelajaran saat memulai pelajaran terkategori sangat tinggi (3.8). Tingkat keterlibatan tersebut dapat dibuktikan dari jumlah guru sertifikasi yang pernah melakukan lima indikator, yaitu sejumlah $69,3 \%$ sampai $100 \%$. Semua responden memberikan motivasi kepada siswa saat memulai pelajaran, dan $69,3 \%$ responden yang melakukan indikator lain.

Kedua peningkatan kualitas proses pembelajaran saat kegiatan eksplorasi. Tingkat keterlibatan guru sertifikasi dalam peningkatan kualitas proses pembelajaran saat kegiatan eksplorasi terkategori sangat tinggi (3.87). Hal ini dapat dibuktikan pada empat indikator yang digunakan untuk mengukur tingkat keterlibatan guru sertifikasi pada indikator tersebut. Tampak, bahwa indikator yang dominan responden lakukan adalah menjelaskan secara detail materi yang diajarkan, yaitu sejumlah $100 \%$ responden. kemudian pada tiga indikator yang lain, tampak bahwa hanya sejumlah 96.3\% responden yang melakukannya. Indikatornya adalah menanyai siswa tentang apa saya yang siswa ketahui berkaitan dengan materi yang akan diajarkan; mencocokkan pengetahuan yang siswa pahami dengan materi pelajaran yang diajarkan; dan menjelaskan kembali materi yang diajarkan.

Ketiga peningkatan kualitas proses pembelajaran saat menyampaikan materi pelajaran. Tingkat keterlibatan guru sertifikasi pada peningkatan proses pembelajaran saat menyampaikan materi pelajaran terkategori sangat tinggi (3.77). Hal ini dapat dibuktikan jumlah guru yang terlibat pada tujuh indikator yaitu 92,9\% dan $96,4 \%$. Terdapat satu indikator yang sejumlah 96.4\% responden yang pernah melakukannya, yaitu membuat siswa termotivasi untuk aktif dalam proses belajar (bertanya, berdiskusi, dan memberikan tanggapan). Sementara indikator yang lain dilakukan oleh sejumlah $92.9 \%$ responden.

Keempat sikap mengajar responden. Sikap mengajar guru sertifikasi saat mengajar terkategori sangat baik/tinggi $(3,79)$. Hal ini dapat dibuktikan jumlah responden yang melakukan tujuh indikator yang digunakan untuk mengukur tingkat sikap tersebut, yaitu $92,9 \%$ dan $96,4 \%$. Ada satu indikator yang sejumlah 96,4\% responden melakukannya, yaitu membuat siswa memahami dengan jelas materi pelajaran. Sementara enam indikator yang lain dilakukan oleh sejumlah 92,9\%.

Kelima peningkatan kualitas proses pembelajaran saat menutup pelajaran. Tingkat keterlibatan guru sertifikasi terhadap peningkatan kualitas proses pembelajaran saat menutup pelajaran terkategori sangat tinggi (3.88). Hal ini dapat dibuktikan pada sejumlah 96,45 responden yang telah melaksanakan 4 indikator untuk mengukur tingkat ketelibatan tersebut.

Keenam peningkatan kualitas madrasah melalui keterlibatan pada madrasah induk. Tingkat keterlibatan guru sertifikasi pada kegiatan madrasah induk terkategori sangat tinggi (3.09). hal ini dibuktikan dengan jumlah responden yang telah melaksanakan kelima indikator yang dijadikan ukuran untuk menentukan tingkat keterlibatan itu, yaitu $82,2 \%$ sampai dengan $92,9 \%$. Dominan responden telah aktif mengembangkan model pembelajaran tertentu (92,9\%). Sejumlah 89,3\% responden telah aktif melaksanakan penelitian dengan melibatkan siswa dan mengajar di luar kelas dengan melibatkan siswa, $85,7 \%$ responden telah aktif melaksanakan kegiatan kompetitif yang melibatkan siswa, dan $82,1 \%$ responden telah aktif menjadi konsultan bagi siswa yang berpresetasi rendah.

Ketujuh tingkat kedisiplinan guru sertifikasi. Tingkat kedisiplinan guru sertifikasi pun tampak sangat tinggi $(3,84)$. Hal ini dapat diamati pada sejumlah $96,4 \%$ responden melaksanakan 5 indikator untuk mengukur tingkat kedisiplinan tersebut.

\section{Keterlibatan Guru Sertifikasi dalam Meningkatkan Kompetensi Sesama Guru}

Terdapat empat aspek yang diamat untuk mengukur tingkat ketelibatan guru sertifikasi dalam meningkatkan kompetensi sesama guru, yaitu kompetensi pedagogik, keperibadian, sosial, dan professional. Pertama keterlibatan dalam meningkatan kompetensi pedagogik sesama guru. Tingkat keterlibatan guru sertifikasi dalam meningkatkan kompetensi pedagogik sesama guru terkategori sangat tinggi (3.49). Hal ini dapat dibuktikan pada jumlah responden yang 
melaksanakan setiap indikator, yaitu 78,6\%-96,4\%. Tampak bahwa dominan responden (96,4\%) telah memotivasi dan berdiskusi dengan sesama guru tentang teori belajar dan prinsip-prinsip pembelajaran, penyelenggaraan penilaian dan evaluasi proses dan hasil belajar. Sejumlah 92,9\% responden telah memotivasi dan berdikusi dengan sesama guru tentang pengembangan kurikulum, pemanfaatan TIK, dan cara memfasilitasi pengembangan potensi siswa. Sejumlah 89,3\% responden telah memotivasi dan berdikusi dengan sesama guru tentang penyelengaraan kegiatan pengembangan yang bersifat mendidik, dan melakukan Penelitian Tindakan Kelas. Dan sejumlah $78.6 \%$ responden elah memotivasi dan berdikusi dengan sesama guru tentang pembagian tugas di antara tenaga kependidikan.

Kedua keterlibatan dalam meningkatkan kompetensi kepribadian sesama guru. Tingkat keterlibatan guru sertifikasi dalam meningkatkan kompetensi keperibadian sesama guru terkategori sangat tinggi $(3,77)$. Hal ini dapat dibuktikan pada jumlah responden telah melakukan lima indikator keterlibantan tersebut, $96,4 \%$ dan $100 \%$. Sejumah $100 \%$ responden telah memotivasi dan berdikusi dengan sesama guru tentang kepribadian yang jujur, berakhlak mulia, dan teladan. Dan terdapat sejumlah 96,4\% responden yang melakukan empat indikator yang lain.

Ketiga keterlibatan dalam meningkatkan kompetensi sosial sesama guru. Tingkat keterlibatan guru sertifikasi dalam meningkatkan kompetensi sosial sesama guru terkategori sangat tinggi (3.79). Sejumlah 96,4\% responden telah memotivasi dan berdiskusi dengan sesama guru tentang berkomunikasi secara efektif, empatik, dan santun, beradaptasi dengan lingkungan tempat bekerja, dan berkomunikasi dengan komunitas profesi guru dan profesi lain. Dan sejumlah 92,9\% responden telah memotivasi dan berdiskusi dengan sesama guru tentang bersikap inklusif, bertindak objektif, serta tidak diskriminatif.

Keempat ketelibatan dalam meningkatkan kompetensi profesional sesama guru. Ketelibatan guru sertifikasi dalam meningkatkan kompetensi profesional sesama guru terkategori sangat tinggi $(3,68)$. Sejumlah $96,4 \%$ responden memotivasi dan berdiskusi dengan sesama guru tentang materi mata pelajaran dan cara menguasainya, standar kompetensi dan kompetensi dasar mata pelajaran dan cara menguasainya, mengembangkan materi pembelajaran, dan memanfaatkan teknologi informasi dan komunikasi. Dan sejumlah 92,6\% responden memotivasi dan berdiskusi dengan sesama guru tentang mengembangkan profesionalitas.

\section{Pemanfaatan Tunjangan Sertifikasi}

Terdapat empat aspek yang digunakan untuk mengidentifikasi pemanfaatan tunjangan sertifikasi guru, yaitu pemanfaatkan pada kepentingan pribadi, kepentingan keluarga, kepentingan peningkatan profesi, dan kepetingan penyediaan sarana pendukung profesi. Pertama pemanfaatan pada kepentingan pribadi. Setelah diidentifikasi, tampak bahwa guru sertifikasi memanfaatkan tunjangan seritifikasi pada kepentingan pribadi yang bervariasi. Guru sertifikasi memanfaatkan tunjangan sertifikasinya pada enam jenis kepentingan yang berbeda. Tampak bahwa dominan responden memanfaatkan tunjangan sertifikasi pada kepentingan kesehatan, yaitu membeli alat kesehatan, obat, vitamin dan lain-lain (61\% responden); kepentingan membeli busana, tas, sepatu (46\% responden); dan kepentingan ibadah haji dan umrah (43\% responden). Selebihnya, terindikasi digunakan untuk menambah modal usaha, membeli perhiasan, baju dinas, dan membantu orang tua.

Kedua pemanfaatan pada kepentingan keluarga. Guru sertifikasi memanfaatkan sebagian tunjangan sertifikasinya secara variatif. Pemanfaatan untuk kepentingan keluarga tersebut teridentifikasi sedikitnya kepada membeli atau kredit kendaraan, membeli/kredit/renovasi rumah, membeli perabot rumah tangga, membiayai pendidiakn anak, rekreasi, sampai kepada membiayai pendidikan suami. Tampak bahwa dominan responden sertifikasi memanfaatkan sebagain tunjangan sertifikasinya kepada membiayai pendidikan anak (75\% responden) dan merenovasi rumah (64\% responden).

Ketiga pemanfaatan untuk kepentingan peningkatan profesi. Pemanfaatan sebagian tunjangan sertifikasi untuk kepentingan peningkatan profesi oleh guru sertifikasi tampak variatif pula. Terindentifikasi sedikitnya lima jenis pemanfaatan, yaitu melanjutkan pendidikan ke strata berikutnya, melakukan penelitian, mengikuti kursus komputer dan bahasa, melakukan studi 
banding, dan mengikuti seminar. Tampak bahwa dominan responden memanfaatkan sebagaian tunjangan sertifikasinya untuk mengikuti seminar (57\% responden) dan melanjutkan pendidikan ke strata berikutnya ( $45 \%$ responden).

Keempat pemanfaatan untuk kepentingan penyediaan sarana pendukung pembelajaran. Pemanfaatan sebagian tunjangan sertifikasi untuk kepentingan penyediaan sarana pendukung pembelajaran oleh guru sertifikasi tampak bervariasi. Guru sertifikasi memanfaatkan sebagai tunjangan sertifikasi dengan membeli sarana pendukung pembelajaran, antara lain: komputer, sarana internet, buku/literatur yang mendukung pembelajaran, media pembelajaran audio visual, dan kamera digital. Tampak bahwa dominan guru sertifikasi memanfaatkan sebagian tunjangan sertifikasinya untuk membeli komputer dan buku paket (96\% responden), media audio visual (68\% responden), dan sarana internet (57\% responden).

\section{Tingkat Dampak Sertifikasi Terhadap Peningkatan Kualitas Madrasah Berdasarkan Karakteristik Guru}

Enam variabel yang dianalisis secara asosiatif untuk mengetahui tingkat dampak sertifikasi guru terhadap peningkatan kualitas madrasah. Keenam variabel itu diklasifikasi kepada variabel karakteristik responden dan variabel indikator dampak. Variabel karakteristik responden meliputi: usia responden saat mengikutis sertifikasi, lama responden mengajar, jalur sertifikasi yang diikuti, status madrasah tempat mengajar, penyelenggara sertifikasi yang diikuti, dan kepangkatan guru sertifikasi. Sedangkan variabel indikator dampak meliputi: peningkatan perencanaan program madarasah, peningkatan pelaksanaan program madrasah, peningkatan proses pembelajaran, peningkatan kompetensi sesama guru, dan pemanfaatan tunjangan sertifikasi.

Pembahasan selanjutnya disistemasi berdasarkan karakterstik responden. Dalam setiap bagian pembahasan karakteristik responden akan diuraikan tingkat dampak sertifikasi berdasarkan lima variabel dampak.

\section{Keterlibatan Responden terhadap Peningkatan Kualitas Madrasah Berdasarkan Perbedaan Usia Saat Sertifikasi}

Usia responden saat mengikuti sertifikasi diklasifikasi kepada 25-33 tahun, 34-43 tahun, 44-
53 tahun, dan 54-60 tahun. Berdasarkan uraian terdahulu bahwa jumlah responden terjaring yang berusia 25-33 tahun adalah 29 orang; 44-43 tahun sebanyak 86 orang; 44-53 tahun sebanyak 11 orang; dan 54-60 tahun sebanyak 34 orang.

Secara umum, tingkat dampak sertifikasi guru terhadap peningkatan kualitas madrasah terkatgori tinggi. Hal ini dapat dilihat pada tingat ketelibatan responden pada berdasarkan klasifikasi usia. Pada aspek perencanaan, responden yang berusia 5460 tahun yang memiliki tingkat partisipasi yang tertinggi, menyusul responden yang berusia 25-33 tahun, kemudian 34-43 tahun. Semua responden yang terklasifikasi dalam kelompok usia tersebut memiliki tingkat keterlibatan pada perencanaan madrasah terkategori tinggi. Sementara responden yang terklasifikasi pada usia 44-53 tahun memiliki tingkat ketelibatan yang terkategori rendah.

Hal yang sama pada aspek pelaksanaan program. Responden yang memiliki tingkat ketelibatan yang terendah yaitu responden yang terklasifiaksi pada usia 44-53 Tahun. Sementara responden yang lain memiliki tingkat keterlibatan pada perencanaan program madrasah terkategori tinggi (34-43 tahun dan 54-60 tahun) dan sangat tinggi (25-33 tahun). Dan pada aspek proses pembelajaran dan peningkatan kompetensi sesama guru, tampak bahwa semua responden memiliki tingkat pertisipasi yang terketegori sangat tinggi dilihat dari keempat klasifikasi usia. Namun aspek pemanfaatan tunjangan sertifikasi, responden masih terfokus pemenuhan kebututhan dasar. Karenanya pemanfaatan tunjangan sertifikasi yang berhubungan langsung pada peningkatan kualitas penddikan di madrasah terkategori sangat rendah, dilihat dari keempat klasifikasi usia responden. Pada tingkat tersebut, responden yang terklasifikasi pada usia 25-33 tahun kemudian 54-60 tahun yang memiliki tingkat pemanfaatan tunjangan sertifikasi tertingi pada peningkatan kualitas pendidikan di madrasah.

\section{Keterlibatan Responden terhadap Peningkatan Kualitas Madrasah Berdasarkan Perbedaan Lama Mengajar}

Berdasarkan lama mengajar, responden terklasifikasi atas empat, yaitu 5-15 tahun, 1626 tahun, 27-37 tahun, dan 38-48 tahun. Pada aspek perencanaan, tingkat keterlibatan responden terbagi atas dua yaitu terkategori sangat tinggi 
(responden yang bertugas selama 16-48 tahun), dan tinggi (responden yang bertugas selama 5-15 tahun). Pada aspek pelaksanaan program tingkat tingkat ketelibatan responden juga terbagi atas dua, yaitu terkategori sangat tinggi (27-37 tahun) dan tinggi (5-15 tahun, 16-26 tahun, dan 38-48 tahun). Pada aspek penigkatan proses pembelajaran dan kompetensi sesama guru, tingkat partisipasi responden terkatigori sangat tinggi di keempat klasifikasi lama mengajar. Sementara pada aspek pemanfaatan tunjangan sertifikasi terkategori sangat rendah di keempat klasifikasi lama mengajar.

\section{Keterlibatan Responden terhadap Peningkatan Kualitas Madrasah Berdasarkan Perbedaan Jalur Sertifikasi.}

Berdasarkan jalur sertifikasi, tampak bahwa pada aspek perencanaan, responden yang mengikuti jalur sertifikasi portopolio lebih tinggi tingkat ketelibatannya (terkategori sangat tinggi) dari pada responden yang mengikuti jalur PLPG (terkategori tinggi). Pada aspek peningkatan pelaksanaan program, responden yang mengikuti jalur sertifikasi portopolio dan PLPG memiliki tingkat keterlibatan yang sama yaitu terkategori tinggi (meskipun angka keterlibatan responden yang mengikuti pola protopolio yang lebih tinggi). Hal serupa pada tingkat keterlibatan responden pada peningkatan proses pembelajaran dan kompetensi sesama guru, reponden yang mengikuti pola portopolio dan PLPG memiliki tingkat keterlibatan yang sama (terkategori sangat tinggi). Demikian halnya pada aspek pemanfaatan tunjangan sertifikasi, responden yang mengikuti kedua pola tersebut dominan memanfaatkan tunjangan sertifikasinya pada kebutuhan dasar, sehingga tingkat pemanfaatan tunjangan sertifikasinya pada hal berhubungan langsung pada peningkatan kualitas pendidikan di madrasah terkategori sangat rendah.

\section{Keterlibatan Responden terhadap Peningkatan Kualitas Madrasah Berdasarkan Perbedaan Status Madrasah}

Tampak bahwa guru sertifikasi yang bertugas pada MAS yang memiliki tingkat keterlibatan lebih tinggi pada penigkatan kualitas perencanaan madrasah dari pada responden yang bertugas di MAN. Namun, responden memiliki tingkat keterlibatan yang sama pada pengingkatan pelaksanaan program, proses pembelajaran, kompetensi sesama guru, dan pemanfaatan tunjangan sertifikasi (tiga aspek pertama terkategori sangat tinggi dan satu aspek terakhir terkategori sangat rendah).

\section{Keterlibatan Responden terhadap Peningkatan Kualitas Madrasah Berdasarkan Perbedaan Penyelenggara Sertifikasi}

Perbedaan tingkat keterlibatan guru sertifikasi pada penigkatan kualitas pendidikan di madrasah berdasarkan perbedaan penyelenggaraan sertifikasi yang diikuti oleh guru tampak. Guru yang disertifikasi oleh Diknas lebih tinggi tingkat ketelibatannya pada peningkatan kualitas perencanaan program madrasah, yaitu terkategori sangat tinggi; sementara tingkat keterlibatan guru yang disertifikasi oleh Kemenag terkategori tinggi. Namun tingkat ketelibatan guru sertifikasi pada aspek yang lain tampak sama, yaitu ketelibatan pada peningkatan kualitas pelaksanaan program terkategori tinggi, proses pembelajaran terkategori sangat tinggi, kompotensi sesama guru terkategori sangat tinggi, dan pemanfaatan tunjangan sertifikasi terkategori sangat rendah.

\section{Keterlibatan Responden terhadap Peningkatan Kualitas Madrasah Berdasarkan Perbedaan Kepangkatan}

Terdapat empat kategori kepangakatan guru sertifikasi, yaitu honorer, golongan III/a dan III/b; golongan III/c dan III/d; golongan IV/ dan IV/b. Tampak bahwa guru sertifikasi yang berstatus PNS memiliki keterlibatan yang tinggi pada peningkatan kualitas perencanaan madrasah (Gologan III/a$\mathrm{IV} / \mathrm{b}$ ), yaitu terkategori sangat tinggi. Sementara guru sertifikasi yang berstatus honorer memiliki tingkat keterlibatan yang terkategori tinggi terhadap peningkatan kualitas perencanaan madrasah. Sementara pada aspek yang lain, semua responden memiliki tingkat keterlibatan yang sama, yaitu keterlibatan responden pada peningkatan pelaksanaan program terkategori tinggi, peningkatan proses pembelajaran kerkategori sangat tinggi, peningkatan kompetensi sesama guru terkategori sangat tinggi, dan pemanfaatan tunjangan sertifikasi terkategori sangat rendah.

\section{Kendala/Permasalahan yang Dialami Guru Seritifikasi}

Selain tingkat keterlibatan atau sumbangsi guru sertifikasi terhadap peningkatan kualitas 
pendidikan di madrasah, penelitian ini juga mengidentifikasi permasalahan yang dialami oleh guru sertifikasi. Berikut ini beberapa permasalahan yang dialami oleh guru sertifikasi di Sulawesi Tengah, antara lain: beban jam mengajar 24 jam dalam seminggu dirasakan tidak seimbang oleh guru sertifikasi dengan penentuan jam setiap mata pelajaran dalam Kurikulum KTSP. Jumlah jam mata ajar yang ditentukan setiap mata pelajaran rata-rata 2-6 jam per mata pelajaran setiap kelasnya, sementara suatu mata pelajaran diampuh oleh 2-4 orang guru. Karenanya, beberapa guru yang mengalami mendapatkan jadwal mengajar yang terhitung tidak mencukupi 24 jam dalam seminggu, terutama guru-guru mata pelajaran agama. Lebih khusus, mata pelajaran Aqidah Akhlak pada kelas XII tidak tercamum lagi sabagai salah satu mata pelajaran yang harus diajarkan. Hal serupa dengan mata pelajaran Bahasa Inggeris, TIK, Bahasa Indonesia.

Solusi yang ditempuh oleh pengelola madrasah dan guru dalam mengantisipasi permasalahan ini, di antaranya adalah memberikan tambahan ajar dengan mata pelajaran yang serumpun. Namun ini tidak maksimal memberikan solusi sebab mata pelajaran yang dimaksud juga diampuh oleh beberapa guru yang lain. Solusi yang lain adalah pimpinan madrasah memberikan tugas tambahan yaitu guru pembina ekstra kurikuler, solusi ini juga tidak maksimal, sebab jumlah ektrakurikuler tidak sebanding dengan jumlah guru, sehingga sejumlah guru tidak mendapatkan tugas tambahan sebagai pembina. Selain itu, kententuan tugas tambahan pembina yang terhitung 2 jam selama seminggu dinterpertasi beragam, antara lain yaitu hanya dua jam per madrasah per semester, sehingga hanya beberapa saja guru yang akan dilibatkan dalam tugas tambahan ini.

Terdapat solusi yang lain yang dominan dilakukan oleh guru sertifikasi yaitu mencari tambahan mengajar di madrasah swasta. Namum pola ini dominan dikeluhkan oleh pimpinan madrasah, sebab guru yang bersangkutan terkadang tidak fokus lagi mengajar pada masdrasah tempat ditugaskan (madrasah induk). Keluhan ini dominan disampaikan oleh kepala madrasah swasta yang memiliki guru sertifikasi. Keterlambatan pencairan tunjangan sertifikasi. Beberapa guru mengalami penundaan mencairan tunjangan sertifikasi, khususnya guru madrasah yang diangkat oleh Kementerian Diknas. Literatur penunjang dirasakan kurang oleh beberapa guru terutama guru mata pelajaran agama. Sarana dan prasarana penunjang pembelajaran dirasakan oleh beberapa guru tidak cukup mendukung proses pembelajaran, khususnya di madrasah swasta. Beberapa guru juga membutuhkan pengembangan kompetensi, khususnya yang berkaitan dengan kompetensi pedagogik dan professional.

Dari sejumlah permasalahan di atas, beberapa usulan solusi yang tawarkan oleh guru sertifikasi dalam upaya mencari solusi pemenuhan ketentuan jam mengajar 24 jam selama seminggu, maka diusulkan agar pemaknaan atas tata muka diperluas, bukan hanya pada pertemuan antar guru dan siswa dalam kelas. Namun kegiatankegiatan pembelajaran yang lain yang melibatkan siswa pun diperhitungkan, seperti kegiatan studi lapangan, penelitian tindakan kelas, merancang dan menyelenggaran kegiatan kompetitif, membuat prototype, dan lain semacamnya. Semua kegiatan itu dapat dilakukan oleh setiap guru sesuai dengan mata pelajaran yang ampuh. Selain itu tugas tambahan adiministratif juga hendaknya dijadikan sebagai bagian penilaian untuk memenuhi 24 jam ajar, seperti tugas tambahan sebagai wali kelas, bendahara, guru piket, dan semacamnya.

\section{PENUTUP}

Tingkat dampak sertifikasi guru terhadap peningkatan kualitas pendidikan di MA di Sulawesi Tengah terkategori tinggi (2,91). Meskipun demikian tingkat keterlibatan atau sumbangsi responden terhadap peningkatan yang dimaksud sebagai dampak sertifikasi guru masih variatif yaitu sangat rendah sampai sangat tinggi. Hal dapat dapat dilihat pada lima aspek yang diamati, yaitu: tingkat keterlibatan atau sumbangsi responden terhadap peningkatan kualitas perencanaan madrasah terkategori sangat tinggi (3.14); pelaksanaan program terkategori tinggi (2,75); proses pembelajaran terkategori sangat tinggi $(3,72)$; dan kompetensi sesama guru terkategori sangat tinggi $(3,68)$. Responden masih dominan memanfaatkan tunjangan sertifikasinya pada pemenuhan kebutuhan dasarnya (kepentingan pribadi dan keluarga) dibanding pada peningkatan kualitas profesi, sehingga terkategori sangat rendah $(0,33)$.

Tingkat dampak sertifikasi guru diamati berdasarkan enam perbedaan karakteristik 
renpondan tampak pula variatif. Tingkat keterlibatan responden terhadap peningkatan perncanaan, palaksanaan program, proses pembelajaran, kompetensi sesama guru terkategori sangat tinggi dan tinggi di empat klasifikasi usia saat sertifikasi, kecuali responden yang disertifikasn pada usia 44-53 tahun tampak memiliki tingkat keterlibatan yang terkategori rendah pada peningkaatan kualitas perencanaan dan pelaksanaan program madrasah. Namun pada lima perbedaan karakteristik responden yang lain-lama mengajar, jalur sertifikasi, penyelenggaran sertifikasi, status madrasah, dan status keguruan/kepangkatan, tampak bahwa tingkat ketelibantan responden pada lima aspek kualitas madrasah terkategori sangat tinggi dan tinggi.

Kendala utama yang dialami oleh guru sertifikasi adalah pemenuhan kententuan regulasi paling sedikit 24 jam tata muka mengajar seminggu. Tatap muka dengan makna memberikan pengajaran dalam kelas paling sedikit 24 jam per minggu sangat sulit dicapai oleh beberapa guru sertifikasi. Olehnya itu guru sertifikasi mengharapkan pengembangan makna tatap muka kepada mencakup kegiatan pengajaran outboard yang melibatkan siswa, seperti studi lapangan, pengamatan sosial, penelitian, perekayasaan ilmiah, kegiatan kompetitif, dan semacamnya. Demikain halnya dengan makna kegiatan tambahan hendaknya kembangkan kepada kegiatan yang bersifat administratif.

\section{Rekomendasi}

1. Sertifikasi guru madrasah hendaknya dilanjutkan dengan melakukan perbaikan pada sistem penyelenggaraannya, karena terbukti memberkan dampak terhadap peningkatan kualitas madrasah. Pola Pendidikan Profesi Guru (PPG) yang dijalankan sekarang merupakan inovasi alternatif yang perlu didukung dengan kebijakan penganggaran yang memadai.

2. Tunjangan sertifikasi, yang dominan dimanfaatkan pada pemenuhan kabutuhan dasar guru sartifikasi perlu diarahkan untuk dimanfaatkan minimal separuhnya untuk kepentingan peningkatan profesi guru.

3. Pengembangan makna tatap muka pada ketentuan regulasi paling sedikit 24 jam pelajaran perlu urgen dilakukan. Karenanya, kajian pegembangan pada Bagian IV Beban Kerja pasal 52-54 Peraturan Pemerintah RI Nomor 74 Tahun 2008 tentang Guru kendaknya dilakukan untuk menginterpertasi dan mengidentifikasi aspek apa saja yang dapat digolongkan sebagai beban kerja dalam pemenuhan 24 jam mengajar.

\section{UCAPAN TERIMA KASIH}

Disadari bahwa penelitian ini usai karena bantuan dari berbagai pihak. Karenanya, saya mengucapkan terima kasih kepada Kepala Balai Litbang Agama yang telah menugaskan saya untuk meneliti Dampak Sertifikasi Guru Madrasah pada Peningkatan Kualitas Madrasah di Kota Palu. Hal serupa saya ucapkan terima kasih kepada Kepala Kantor Wilayah Kementerian Agama Provinsi Sulawesi Tengah, seluruh pejabat dan staf Bidang Pendidikan Madrasah, serta seluruh kepala madrasah baik negeri dan swasta. Bantuan tenaga dan informasi yang telah diberikan kepada saya sangat mendukung suksesnya penelitian ini.

\section{DAFTAR PUSTAKA}

Sunendar, Dadang; Yoyoh Jubaedah; Tri Indri Hardini. Dampak Penyelenggaraan Sertifikasi Guru Terhadap Peningkatan Profesionalisme Guru (Studi Deskriptif Dampak Penyelenggaraan Sertifikasi Guru Terhadap Peningkatan Profesionalisme Guru SMA di Jawa Barat), http:// lppm.upi.edu.

Mardapi, Djemari dkk. Studi Dampak Sertifikasi Guru Terhadap Prestasi Sekolah, http://staff.uny.ac.id.

Dye, Thomas R. 1978. Understanding Public Policy. Prentice Hall Inc: New Jersey.

Fatchurrohman. Pengaruh Sertifikasi Bagi Peningkatan Kinerja Guru SMP Negeri 1 Salatiga, http:// eprints.stainsalatiga.ac.id.

Kementerian Pendidikan Dan Kebudayaan. 2012. Sertifikasi Guru Dalam Jabatan Buku 1 Pedoman Penetapan Peserta. Jakarta: Badan Pengembangan Sumber Daya Manusia Pendidikan Kebudayaan Dan Penjaminan Mutu Pendidikan.

Kementerian Pendidikan Dan Kebudayaan. 2012. Sertifikasi Guru Dalam Jabatan Buku 2 Petunjuk Teknis Pelaksanaan Sertifikasi Guru di Rayon LPTK. Jakarta: Badan Pengembangan Sumber Daya Manusia Pendidikan Kebudayaan Dan Penjaminan Mutu Pendidikan.

Kementerian Pendidikan Dan Kebudayaan. 2012. Sertifikasi Guru Dalam Jabatan Buku 3 Pedoman Peyusunan Portofolio. Jakarta: Badan Pengembangan Sumber Daya Manusia Pendidikan Kebudayaan Dan Penjaminan Mutu Pendidikan.

Situs Direktorat Jendral Pendidikan Agama Islam Kementerian Agama Republik Indonesaia, http:// pendis.kemenag.go.id/index.php. 
Situs Direktorat Pendidikan Madrasah Direktorat Jendral Pendidikan Agama Islam Kementerian Agama Republik Indonesia. http://madrasah.kemenag. go.id

Soemarwoto, Otto. 2004. Ekologi, Lingkungan Hidup dan Pembangunan. Jakarta: Penerbit Djambatan.
Sugiyono. 2010. Metode Penelitian Kuantitatif Kualitatif dan R \& D. Bandung: Penerbit CV. Alfabeta.

Suryadi, Ace dan H.A.R Tilaar. 1993. Analisis Kebijakan Pendidikan Suatu Pengantar. Bandung: PT. Remaja Rosdakarya.

Suwardi. Dampak Sertifikasi Terhadap Peningkatan Kualitas Guru, http://Eprints.Stainsalatiga.ac.id. 